\title{
Re-contextualisation and the Transformation of Meanings: A Critical Discourse Analysis of the Islamic State Pedagogical Discourse in Iraq
}

\author{
Khalid Shakir Hussein * \\ Thi-Qar University/ College of Arts/ Iraq
}

\begin{tabular}{llllll}
\hline Received: 15.02 .2021 & • & Accepted: 12.05.2021 & • & Published: 30.06.2021 & • Final Version: 30.06.2021
\end{tabular}

\begin{abstract}
This article is an attempt to investigate the recontextualisation and transformation process involved in the pedagogic discourse of Islamic State classroom textbooks during its takeover of some parts of Iraq. The article uses an eclectic analytical framework comprising Bernstein's pedagogical model of recontextualization, Linell's levels of recontextualization, Fairclough's concept of genre mixing, Wodak's discourse-historical approach (DHA), and Barthes' model of visual semiotics. These mixed approaches are applied to the analysis of a variety of visual images of Islamic State published textbooks and classroom pedagogic visual aids downloaded from different websites. It is found that the meaning of the pedagogic discourse is transformed via interdiscursive recontextualisation processed in two reversal directions: a militarization of pedagogic discourse and a pedagogization of decapitation practice. Recontextualisation is exceptionally significant with regard to Islamic State jihadist pedagogic discourse that is reframed historically and ideologically to suit an extreme sense of religious intolerance which Islamic State prioritizes as a foundation of regaining and refreshing their lost Islamic caliphate.
\end{abstract}

Keywords: recontextualisation, critical discourse analysis, multimodality, pedagogical discourse.

\section{Introduction}

Not too many studies have investigated the pedagogical effect of the Islamic State's discourse. Olidort (2016), for example, has studied the Islamic State's (henceforth IS) Arabic language textbooks and pamphlets making a unique contribution to a better understanding of the way IS functions as a terrorist organization. Likewise, Rabil (2018) made an in-depth investigation of the historical roots of the concepts of Jihad and Takfir within the context of the Sunni conceptual framework that could be an excellent trigger of the Jihadi discourse adopted later by IS. What is more, Ali (2021) has gone through the language policy of IS with a specific foucs on what is called linguistic cleansing in its educational system.

This paper comes as a further attempt to investigate the process of recontextualisation observed in the Islamic State's pedagogical discourse. The researcher argues that during its takeover of some Iraqi provinces, IS offered a pedagogical discourse, represented in its published textbooks, that seems to be a product of recontextualizing both a militaristic version of Jihad discourse and a pedagogizing version of beheading practice. IS intended to recontextualize the meanings of Jihad

\footnotetext{
* Corresponding Author: Khalidshakir74@gmail.com
} 
and Islamic pedagogy in a way that they are both redefined within the new context of the Isization program.

As a process recontextualisation presupposes first extracting an element out of its given context via a process usually called decontextualisation. Only after being decontextualized the element is ideologically re-positioned, recontextualized or inserted into a different context that likely triggers a change in the meaning of the transferred element itself (Bernestien, 1990: 193). Therefore, the researcher seeks to explore the way decontextualisation and recontextualisation are manipulated by IS so that violent redefinitions of jihad and pedagogy are provided and endorsed in its classroom textbooks.

\subsection{Recontextualisation in Discourse Studies}

As a concept recontextualisation has been developed first by Bernstein (1990), a British educational sociologist. In his The Structuring of Pedagogic Discourse (1990) Bernstein uses recontextualisation to understand the nature of the pedagogic discourse and the way educational knowledge is structured. Nevertheless, the area of discourse analysis witnessed fruitful and extensive applications of the concept of recontextualisation to study the nature of the discursive and intertextual relations holding between various discourses and texts (see Bauman, 1990; Blommaert, 2005; Fairclough, 2003; Linell, 1998).

The significance of recontextualisation in discourse analysis is primarily derived from the very fact that relocating or resituating a text or discourse would bring about a change or transformation of their meanings (Connolly, 2014: 377). To transfer an element from its original discourse, or textin-context, and reuse it in a new discourse is to re-center or redefine its meaning. The new context of use supplements the element with further dynamic contextual meaning that modifies its original one if not transforming it altogether.

This change in meaning is a primary function of recontextualisation which cannot be achieved without linking certain texts or discourses. The process of such a recontextualized linking proceeds across three levels (Linell, 1998): intratextual level, where recontextualisation occurs within the same text or discourse with somewhat anaphoric and cataphoric referencing; intertextual level, where recontextualisation occurs across different texts, or discourses mixing up their own different contexts; and interdiscursive level, where recontextualisation cuts across different types of discourse or genres in a way that one given type of discourse is recontextualized or embedded in a configuration of another discourse type (Kong, 2009: 116).

The data to be analyzed in this paper come under the recontextualized umbrella of interdiscursivity. Thus, the next section will go through the way recontextualisation is put at work across the specific level of interdiscursivity.

\subsection{Interdiscursive Recontextualisation}

The level of interdiscursivity is characterized by a diversity of relations that hold between a variety or a mix of discourses and genres. Therefore, it is expected to have a sort of multimodality or interdiscursive hybridity that surfaces due to a variety of semiotic modalities being brought together or recontextualized in a novel multimodal discourse. It is still one of the basic concerns of 
multimodal semiotics to investigate the way language, images, photographs, videos and other resources are interacted in one hybrid semiotic modality (Kress and Van Leeuwen, 2001).

Language is no more the sole focus of discourse analysis. Other semiotic systems are taken into consideration in relation to language. Meaning potential is negotiated through the style different communicative modes are combined in a single multimodal discourse (Kress and Van Leeuwen, 2001).

The style of interdiscursive recontextualisation is usually conditioned by ideological interests and bias interpretations of discourse. As an example of this multimodal recontextualisation, jihad discourse is ideologically and pedagogically framed and reinterpreted by IS through an interdiscursive process of meaning-making. Section 4 below will sketch the canonized Islamic interpretations of jihad discourse to set the scene for the violent interpretations contributed and endorsed by the IS via its legitimized pedagogic discourse.

\section{Jihad Discourse: A Historical Perspective}

The concept of Jihad is malleable and has multifaceted articulations within the context of the Islamic jurisprudence. Nevertheless, whatever interpretation one can have of jihad it should have its ideological roots in the Qur'an and the prophetic traditions (Hadith).

Arabic etymology makes it clear that jihad is a word with a broad meaning that ranges from "to strive", "to struggle", "to put effort into achieving an objective", to "to make a determined effort" (see Asfahani 1971, Mansur 1992, Katsir 1972, Al-Tabari 2000, and Ma'luf 1986). No direct reference is made evidently to war or violence.

Generally speaking, Jihad is vaguely identified by the Qur'an as (Jihad fi sabil Allah) or Jihad in the course of Allah. This is a characterized interpretation of Jihad discourse that goes exclusively in line with Allah's divine instructions. Nevertheless, Jihad discourse has recursively been displaced or decontextualized from its original Arabic etymological context, mentioned above, and relocated in accordance with the sociopolitical shifts which Prophet Muhammad experienced throughout his long and stressful strife (jihad) to develop and spread Islam.

This process of decontextualization and recontextualisation of Jihad discourse recurred and fluctuated along two periods of the early Islamic history: Meccan period and Medina period. The Qur'anic verses revealed in Meccan period recontextualized a rather passive interpretation of Jihad discourse that narrowed down its broad meanings to an effortful and exclusive broadcasting of the new religion against its overwhelming pagan environment. As for Medina period, Prophet Muhammad's forced migration from Mecca to Medina triggered another type of Qur'anic verses with a process of decontextualization proceeded to reframe Jihad discourse as an active and defensive practice indispensible for the expansion and prosperity of the new religion (see Rabil, 2018, alQaradhawi, 2009).

The prophetic hadith, or reported sayings, of Muhammad produced further recontextualized elaborations of the Qur'anic interpretations of Jihad discourse. Jihad is redefined and reworked into a new dichotomy of spiritual versus physical struggles. In a highly cited prophetic reported saying Muhammad makes a clear and quite interesting distinction between the greater jihad and the smaller Jihad. On the one hand, the greater jihad is an inward and daily struggle against the believer's sinful inclinations. This spiritual version of jihad discourse is reframed in a new context that transforms the meaning of Jihad into a daily practice intended to protect the Islamic identity of the believer. On 
the other, the smaller Jihad is a physical outward struggle or a holy war that is waged in defense of Islam (see Peters, 1979).

Historical recontextualisations of Jihad discourse never stop transforming its meanings and reinterpretations by inserting it over and over again into a new set of sociopolitical contextual relations. Therefore, in the post-prophetic period (7th and 8th centuries), when the Islamic empire emerged actively, Jihad acquired a new redefinition that equated it with a conception of warfare. The rapid expansion of the Islamic empire required sacred mobilization and recruitment of Muslim communities to legitimize a form of Islamic hegemony over the newly conquered non-Muslim areas. This might explain why the Islamic scholars and jurists then contributed a sort of holy war recontextualisation of Jihad discourse (Hassan, 2008).

The anti-colonialism period (18th-20th centuries) triggered another process of recontextualisation that reinterpreted Jihad discourse as an ideology of resistance and liberation. This redefinition surfaced as a revolutionary response against the colonial governments of Muslim countries. What is more, the post-colonial period (mid to late 20th century) witnessed a rather global reframing of Jihad discourse being recognized within a new context of military and political struggle against the West/US hegemony (Hassan, 2008: 126).

This post-colonial recontextualisation is quite diverse and global. It redefined the limits of Jihad discourse to include a wide variety of Jihadi reinterpretations and actions such as the struggle to bring about the Islamic or Caliphate state, offensive armed movements against any forms of western hegemony, and the martyrdom operations that recontextualized the body of the suicider as a sacred jihadi weapon (Peters, 1979). This highly offensive and militarized recontextualisation of Jihad discourse has spread throughout different Islamic ideological communities and different parts of the world.

Accordingly, transnational recontextualized interpretations of Jihad discourse have been legitimized under the ideological influence of the puritanical salafi jihadi school of Islam founded in Afghanistan during the Soviet Union occupation. It is under the umbrella of the Salafi armed interpretations that Jihad discourse was extremely reshaped by the ideological authority of al-Qaeda and later by its off-shoot or IS.

\section{Methodology and Data Analysis}

The data to be analyzed throughout this study constitute a variety of fifteen visual images taken from IS published textbooks and classroom pedagogic visual aids downloaded from different websites such as jihadology.net, http://www.clarionproject.org/news/islamic-state-isisisil-propaganda-magazine-dabiq, https://www.pinterest.com/wisdpisocstu/isisisil-resources-for-teachers/, and https://www.businessinsider.com/isis-textbooks-2016-8 (see Appendix). As for the methodology, this study would attempt a thematic classification of images beside drawing upon an eclectic analytic framework comprising a group of discursive perspectives: Bernstein's (1990) pedagogical model of recontextualization, Linell's (1998) levels of recontextualization, Fairclough's (2003) genre mixing, Wodak's (2009) discourse-historical approach (DHA), and Barthes's (1977) model of visual semiotics. Therefore, Bernstein's distinction of pedagogic discourse into instructional and regulative is taken into consideration. Pedagogic discourse for Bernstein included both the discourse of skills and knowledge that he called 'instructional', and the creation 
of social order, relations and identity that he termed 'regulative'. With this perspective the regulative relation between the verbal text and the accompanied images is investigated together with Barthes' semiotic model of image-text relation. Recontextualisation is addressed across Linell's three levels with a special focus on the interdiscursive level. Fairclough's concept of genre mixing is a further enrichment of the text types being recontextualized. As for Wodak's DHA, the historical context of the jihad discourse could play a significant role in reconstructing the way recontextualisationworks as a linking process that cuts across a variey of jihad, pedagogic, and military discourses.

\section{Data Analysis: Discussion and Findings}

\subsection{IS Jihadist Pedagogical Discourse}

Though IS shares basically the same ideological interpretation of Jihad discourse as that of Al-Qaeda, its version of Jihad is still recontextualized within a more hostile, and offensive context of dehumanizing and exterminating both Muslims and non-Muslims. All Muslims who operate outside the legitimized IS interpretation of Jihad discourse are apostasied and accordingly put to death within the context of IS version of Salafist Islamic jurisprudence (see Olidort, 2016:25-32).

Unlike many other salafi movements IS has had its own endorsed publications that promoted and propagandized its own controversial redefinition of Jihad discourse within a complementary context of takfir hallmarks. IS publications fall into two types: propaganda magazines such as Dabiq and Rumiyah which were online magazines used by the IS for Islamic radicalisation and recruitment, and pedagogy or classroom textbooks (see Patrick et al., 2016).

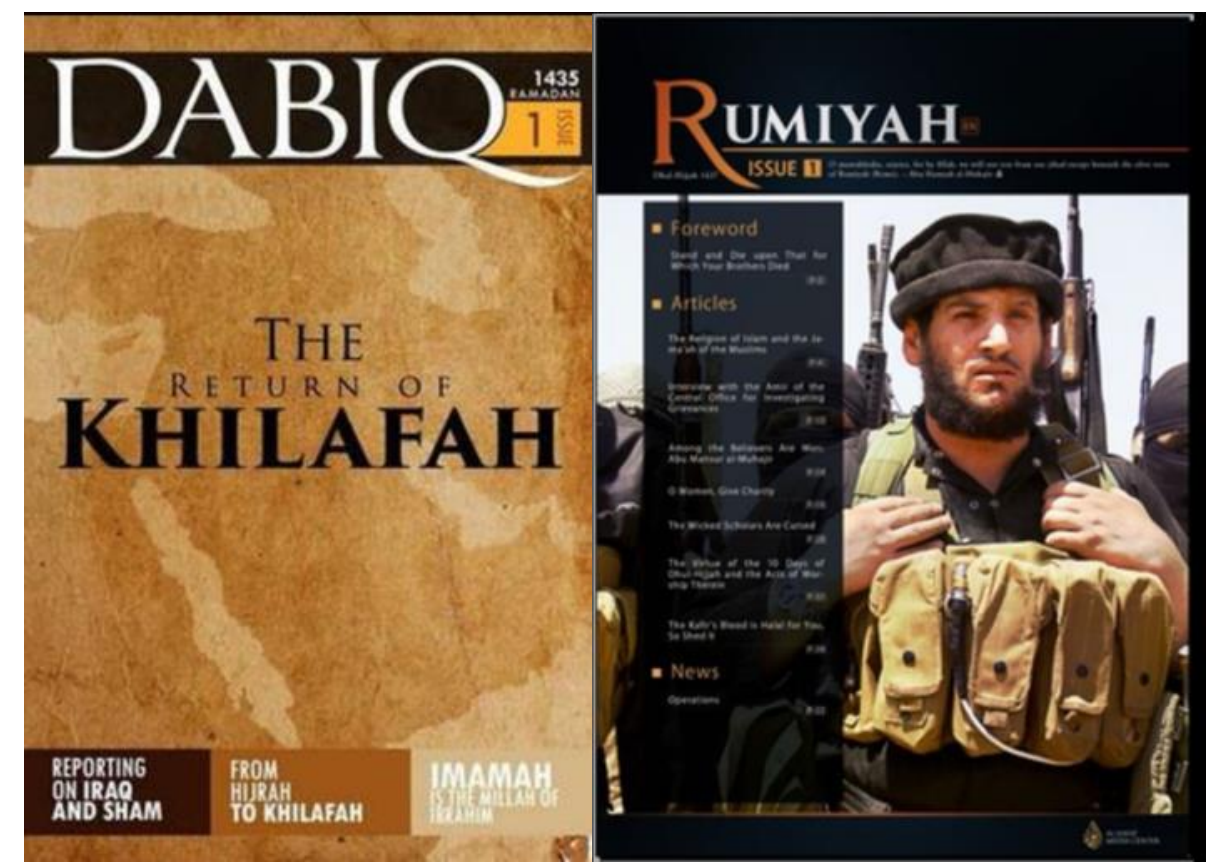

Figure 1. Cover Photos of IS's primary propaganda magazines of Dabiq and Rumiyah

What captures the researcher's interest is the nature of the jihadist pedagogic discourse which was legitimized and recontextualized within the context of the classroom textbooks published and taught under the authority and legitimization of the IS. The pedagogic discourse of IS offers insights into 
the way IS responds to the requirements of maintaining its jihadi ideological brand alongside its publishing activities within the restricted context of its educational program.

What distinguishes IS in Iraq from other Salafist and jihadi groups is its pedag ogic ambitions which have been laid out in a subtle and ideologically oriented recontextualisation of militarized textbooks and pedagogized form of merciless violence. The following two sections will go through a number of classroom textbooks published and taught by IS teaching staff in Iraq.

\subsection{Militarization of Pedagogical Discourse}

Some characteristics of IS attempts to redefine jihad discourse lie in its published classroom textbooks. The pedagogical program of IS shapes and recontextualizes the unreligious content of the textbooks to be in line with its jihadi cause and goals. The way IS presents textbooks on physical preparedness, history, geography, and mathematics is conditioned by a persistent propensity to decontextualize the military discourse from its familiar context and mix it with the pedagogic discourse presented in the classroom textbooks. This interdiscursive recontextualisation across military and pedagogic discourses is probably a defining feature of what might be called an isization of pedagogic discourse.

The IS textbooks include a variety of stable characteristics that suit its general pedagogic program. Images are but one of these characteristics that define the orientation of the pedagogic discourse presented in IS textbooks. A specific type of images is subtly interwoven with the nonreligious pedagogic content of the textbooks. The images of guns outlines in particular and diagrams of weapons assembly are unlikely relocated at the bottom of each chapter in IS textbooks on Arabic literature, mathematics, Arabic grammar, and physical preparedness (see Figures 2 and 3).
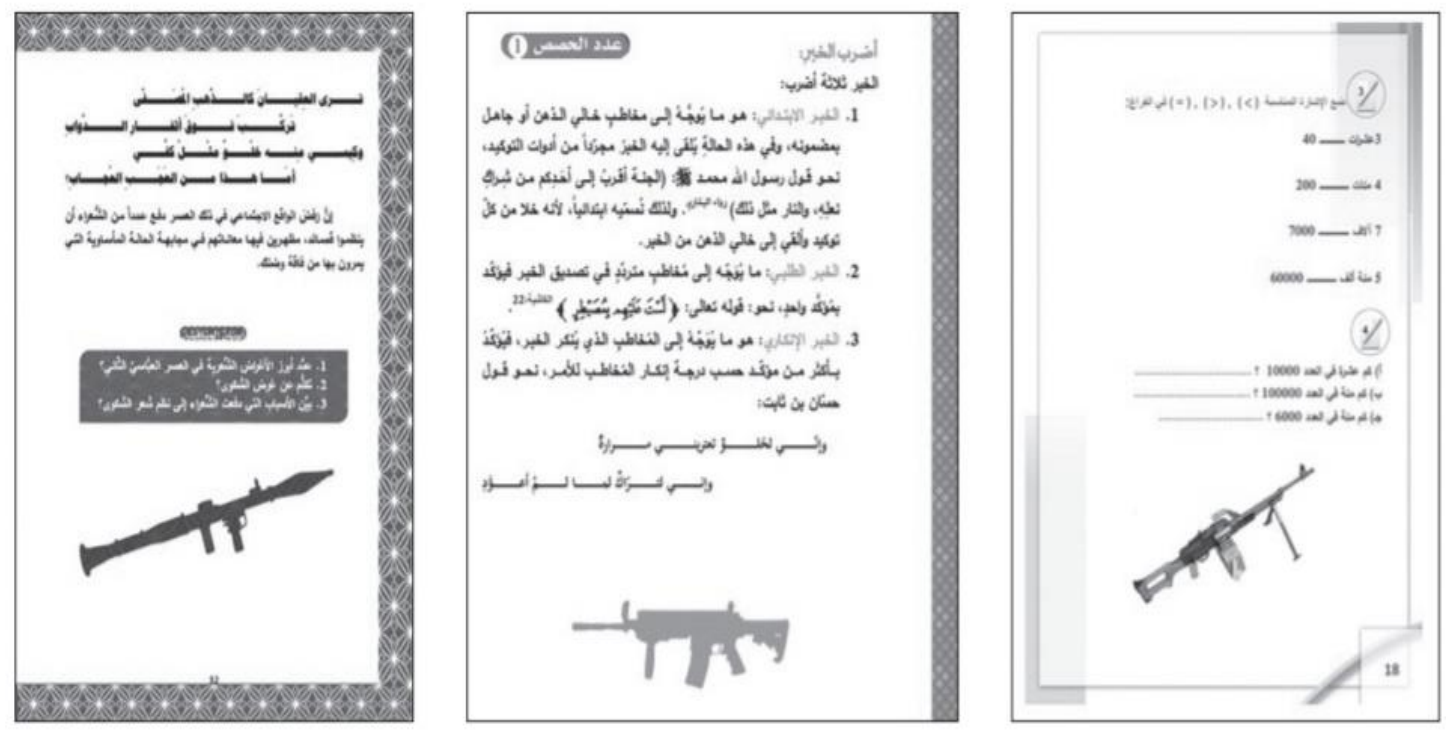

Figure 2. Three pages taken form the textbooks on Arabic literature; grammar; and mathematics 

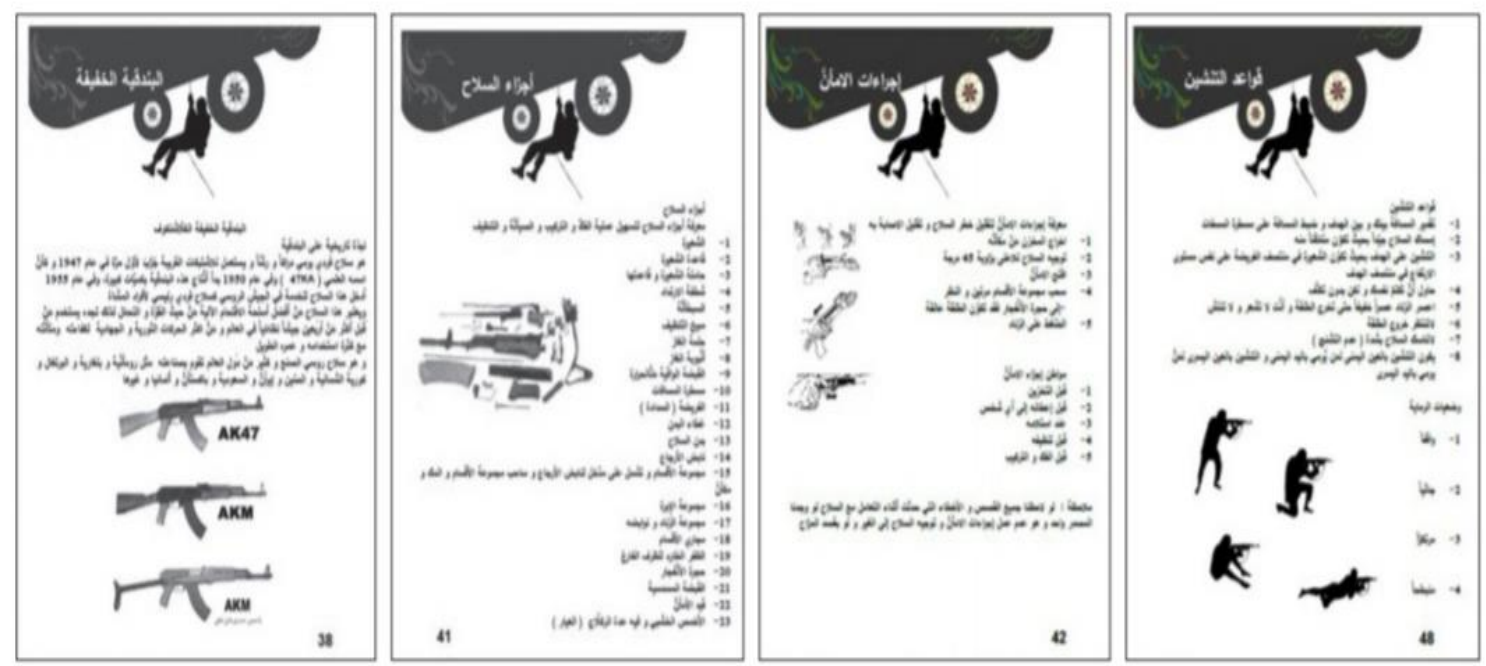

Figure 3. Four pages taken from the textbook on physical preparedness

What is more, weaponry images and IS flag are recontextualized within the pedagogic discourse involved in the form of drills or pedagogic visual aids presented over the pages of mathematics textbooks (see Figure 4).
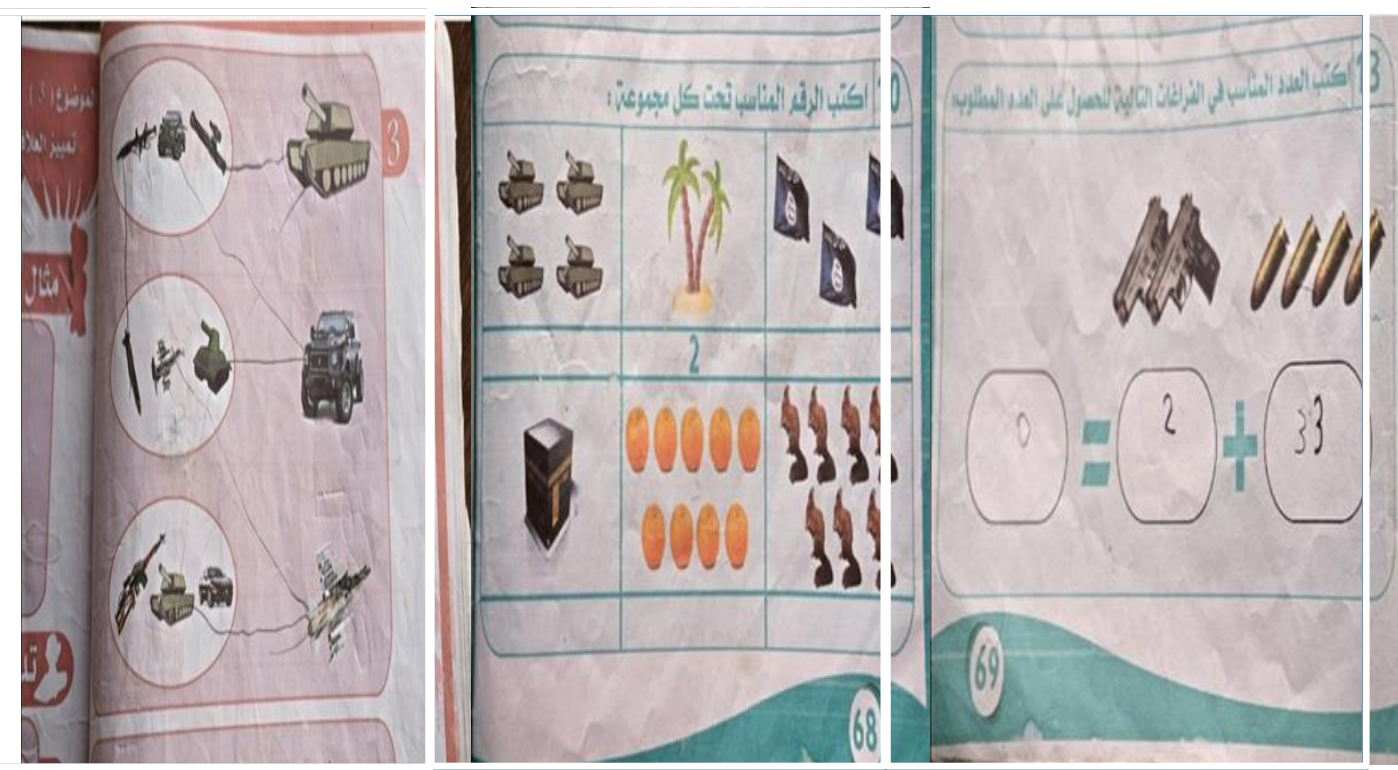

Figure 4. Three pages taken from the textbook on mathematics

This kind of interdiscursive recontextualisation might be simply seen as an unsophisticated endorsement of violence. The guns outlines are decontextualized from their natural military discourse and inserted into the pedagogic discourse of IS textbooks (see Figure 5). These transferred weaponry outlines acquire a change in their meaning after being relocated within the interpretative network usually triggered by the pedagogic discourse. The recontextualized new meaning is not simply a reinforcement of violence in the pedagogic program of IS. Rather, it is likely an attempt to restore and trigger a lost militaristic dimension of the Islamic pedagogical discourse defined within the broader framework of Jihad discourse 


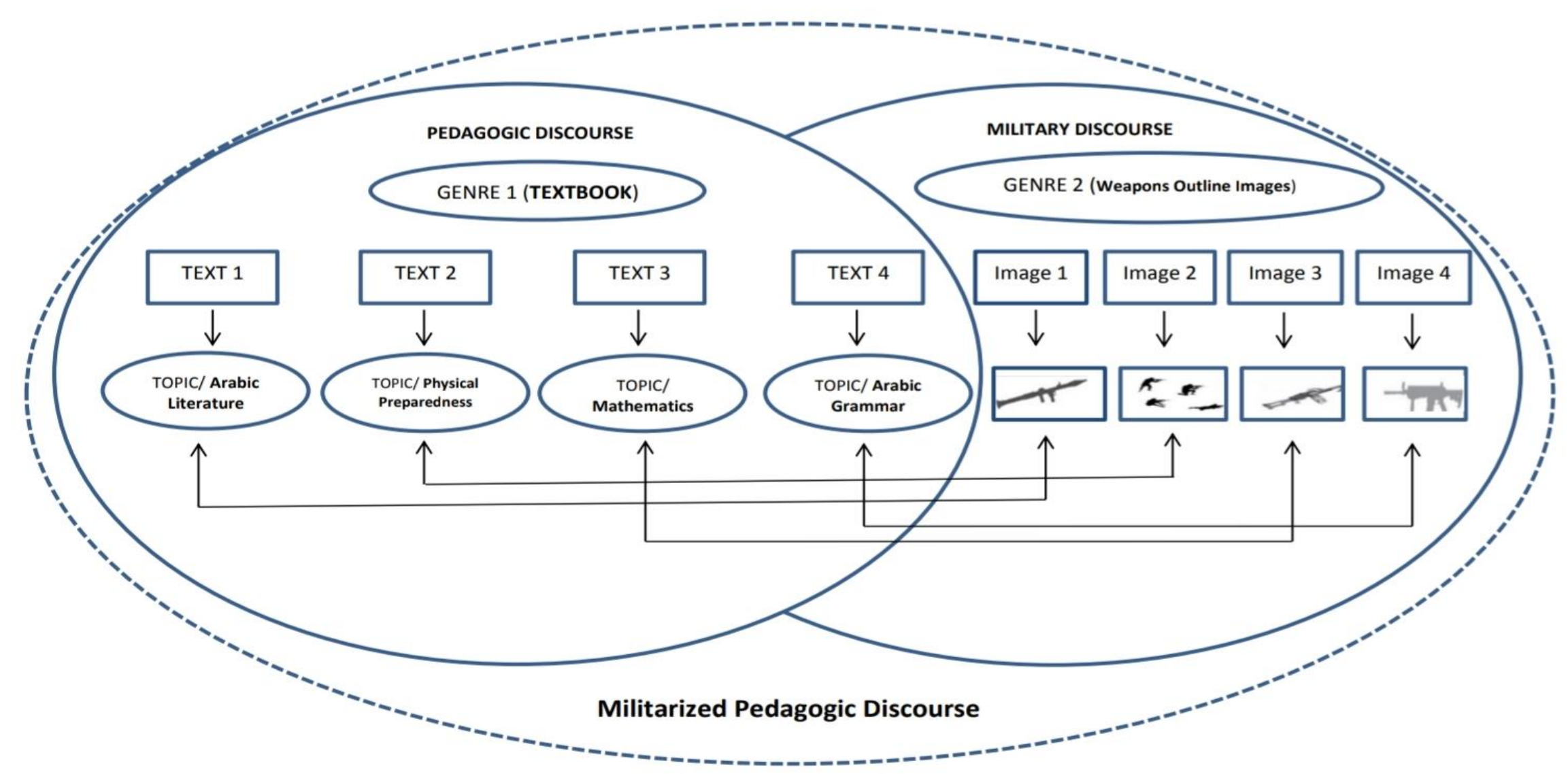

Figure 5. A schematic representation of the militarized recontextualisation of pedagogic discourse 
Jihad discourse can actually be viewed and interpreted within the historical context of the prophetic hadith (reported sayings) across a variety of theological levels: the lowest and weakest level of Jihad is to reject vice by the heart and the highest is to fight physically in the path of Allah's divine codes.

There exist levels of Jihad discourse which can be found in a complex series of sublevels, one of them is related to seeking knowledge (Azra, 2000:14). People involved in seeking knowledge are viewed as some sort of strivers and fighters in the path of Allah. It is famously reported that Prophet Muhammad said "Whoever goes out seeking knowledge is in the path of Allah until he returns" (see Sunan al-Tirmidhi 2647). Therefore, Jihad presents an overarching discourse under which pedagogic discourse, beside other ones, can be practiced and reframed. It is part of IS pedagogic program to recall and recontextualize its classroom textbooks within the rather forgotten jihadistic dimension of the Islamic pedagogy.

\subsection{Pedagogization of Decapitation Practice}

Among the most distinguishing features of IS violence discourse is the increasing attention being given to the educationalized aspect of violence. It was part of IS pedagogic program to have children subject to some training camps held particularly in Mosul and Raqqa. Children go through a series of physical and military trainings involving, but not restricted to, guns handling, physical preparedness, and the practice of decapitation (Olidort, 2016:9).

Decapitation is relocated within an educational context and redefined as a pedagogized action that can be shaped by the act of teaching. Children were taught to practice decapitation on blondhaired dolls (see figure 6.). This is achieved not only through hands-on training but also through an educational and pedagogic process where the practice of decapitation is presented and recontextualized as a pedagogic skill to be performed by learners.

IS textbooks provide skill training of beheading via some proceduralized images of the stages involved in what IS views as an Islamically legitimate way of practicing the act of decapitation.
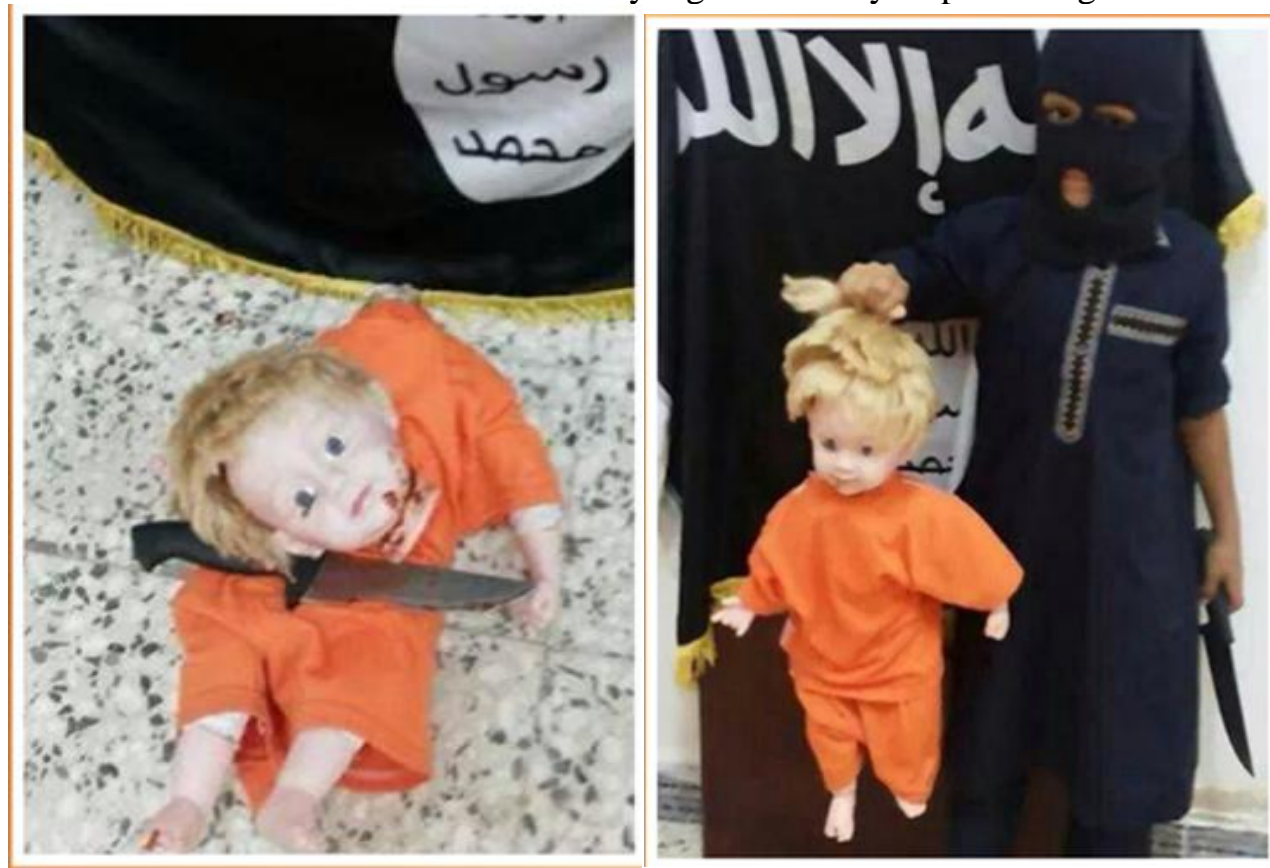

Figure 6. A child practicing decapitation on a blond-haired doll 
Therefore, IS unprecedently reframes decapitation, the most violent and lethal activity, in ways that blend two genres together in one new and recontextualized discourse. The genre of beheading practice manual is interwoven with the genre of pedagogic visual aids (see Figure 7). The outcome of such a genre blend transforms the meaning of decapitation as an extremely violent practice and reframes it as a proceduralized and pedagogized skill of learning.

This new pedagogic recontextualisation of decapitation is shaped by the historical perspective IS adopts to restore the procedural aspect of decapitation as it had been practiced by Kharijites. The Kharijites were a dissident islamic sect notorious for its uncompromising ideology of takfirism and violence. It appeared in the first century of Islam after breaking away from the Caliph Ali's army. It is most likely that the practice of decapitation adopted by IS was originated from the Kharijites (see Sulaiman, 2017).

The executioner uses a sword, or a sharp blade, to remove the condemned person's head from his or her body at the neck with a single strike. After the convicted person is slaughtered, the executioner takes off the head and places it on the convict's chest. These two stages of decapitation were stressed and pedagogized within the context of what looks like visual aids presented in the IS media propaganda and classroom textbooks on physical preparedness. 


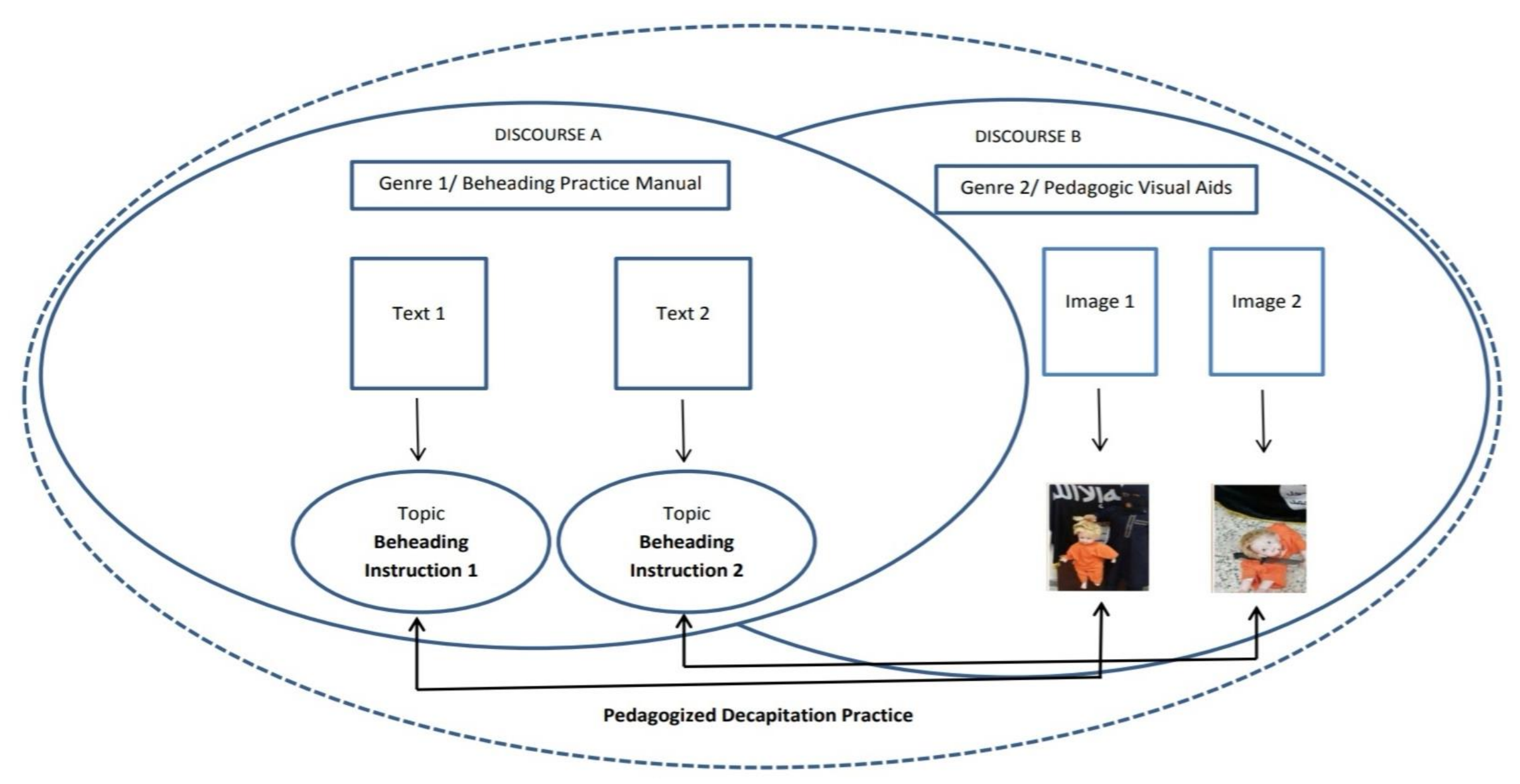

Figure 7. A schematic representation of the pedagogized recontextualisation of decapitation practice 


\subsection{IS Recontextualized Pedagogic Discourse Across Image-Text Relations}

The meaning of images cannot be excluded from the verbal texts. The visual meaning attributed to a given image cannot be stabilized or even anchored without the indispensable mediation of language. This instability of visual meanings can be fixed by a variety of techniques (see Barthes, 1977; Kress and Leeuwen, 2006). Interdiscursive recontextualisation is but one example of such techniques. Image-text relations can be rather an overarching landscape for interdiscursive recontextualization. That is, images can be decontextualized from their familiar context and reframed within a given textual context. This process involves a transformation of either the visual meaning or a slight modification of the textual meaning. It actually depends on which part is dominant of the image-text relations (Kress and Leeuwen, 2006:18).

Therefore, in the case of the militarized pedagogic discourse investigated throughout this paper the verbal text is always the classroom textbooks and the visual images are always related to guns outlines. Most of these outlines are iconic, simple, ready-made, and black echoing IS flag color. Being sources of meanings, these two semiotic modalities, verbal texts and visual images, are deployed in various ways within the IS educational program to bring militaristic meanings into the pedagogic discourse, and to recontextualize interdiscursive meaning of Jihad discourse. Hence, sometimes the relation between the two modalities is completely out of place (guns outlines at the bottom of each chapter of textbooks on Arabic literature, Arabic grammar, and mathematics), and some other times the relation appears ostensibly pedagogic in the form of visual aids in mathematic drills.

As for the case of why not teaching and promoting through school textbooks the practice of decapitation, the visual modality, represented by the two images of beheading practiced by a child, is by far the dominant part of the image-text relation. Though the visual meaning of the two images looks self-evident, it is enhanced and extended by the propaganda recontextualisation of the accompanied verbal text represented by Abu Bakr Al-Janabi's tweet, "And some entertainment for the next generation of Mujaheddin." ( see Figure 8). 


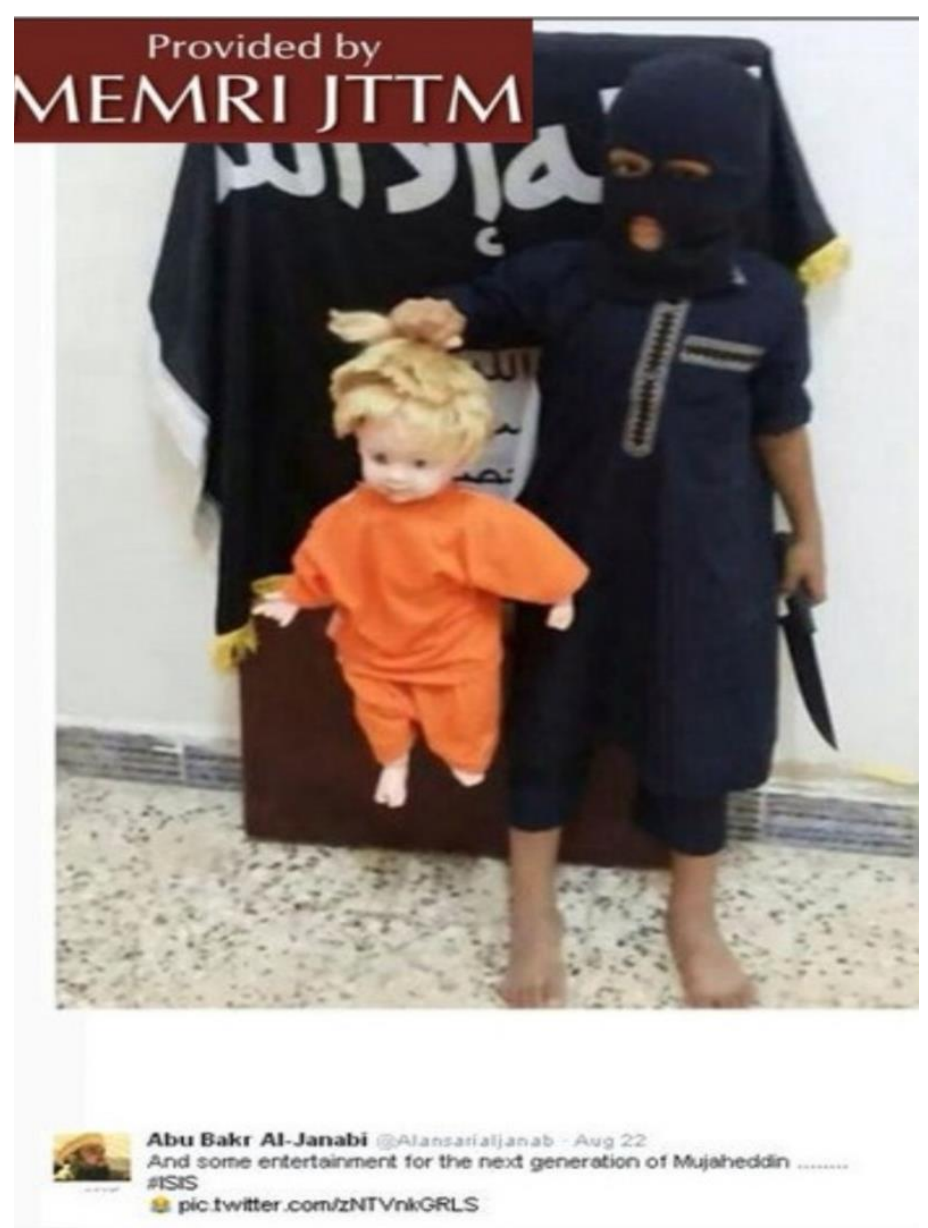

Figure 8. A screenshot of Abu Bakr Al-Janabi's tweet, "And some entertainment for the next generation of Mujaheddin." accoimpanied by a photo of a child practicing decapitation on a blond-haired doll

\section{Conclusions}

The way IS utilized recontextualisation throughout its pedagogical program appears rather sophisticated, historically oriented and two folded. The meaning of the pedagogic discourse is transformed via interdiscursive recontextualisation processed in two reversal directions: $a$ militarization of pedagogic discourse and a pedagogization of decapitation practice. The first extends the meaning of the pedagogic discourse from its pure educational aspect to a sort of Islamic semiotic landscape based on a physical sense of jihad discourse. The second radically reframes the act of beheading as a pedagogically permissible act. This process involves a double transformation of meanings: the meaning of the decapitation practice is changed under the influence of another change of meaning of the pedagogic discourse. The result is a sort of overarching pedagogic discourse that could harmfully pedagogize and legitimize even the most lethal and brutal practices.

Therefore, recontextualisation is exceptionally significant with regard to IS jihadist pedagogic discourse that is reframed historically and ideologically to suit an extreme sense of religious intolerance which IS prioritizes as a foundation of regaining and refreshing their lost Islamic caliphate. 


\section{References}

[1] Ali M (2021) The language policy of the Caliphate State. Middle Eastern Studies 57:2, 391405, DOI: $10.1080 / 00263206.2020 .1842370$.

[2] Asfahani R (1971) Mufradat Alfadh al-Qura'an. Beirut: Daar al- Kutub al-'Ilmiyah.

[3] Azra A. (2000) Islam Substantif: Agar Umat Tidak Jadi Buih. Bandung: Mizan.

[4] Barthes R (1977) Image-Music-Text. (S Heath Trans.). London: Fontana.

[5] Bernstein B (1990) Class, Codes and Control, Vol. IV: The Structuring of Pedagogic Discourse. London: Routledge.

[6] Blommaert J (2005) Discourse. Cambridge: Cambridge University Press.

[7] Bauman R (1990) Poetics And performance as critical perspectives on language and social life. Annual Review of Anthropology 19 (1): 59-88.

[8] Connolly H (2014) Recontextualisation, resemiotisation and their analysis in terms of an FDG-based framework. Pragmatics 24 (2): 377-397.

[9] Fairclough N (2003) Analysing Discourse: Textual Analysis for Social Research. London and New York: Routledge.

[10] Hassan R (2008) Inside Muslim Minds. Melbourne: Melbourne University Press.

[11] Katsir I (1972) TafsirIbnKatsir. Juzua I. Beirut: Dar al-Fikr.

[12] Kong C (2009) Interactions of professional, institutional and business discourses in academic settings. In: Winnie C and Kong C (eds) Professional Communication: Collaboration between Academics and Practitioners. Hong Kong: Hong Kong University Press, pp.113-27.

[13] Kress G and van Leeuwen T (2001) Multimodal Discourse. London: Arnold.

[14] Kress G and Van Leeuwen T (2006) Reading Images. London and New York: Routledge.

[15] Linell P (1998) Discourse across boundaries: on recontextualizations and the blending of voices in professional discourse. Text- Interdisciplinary Journal for the Study of Discourse 18: 143-57.

[16] Ma'luf L (1986) al-Munjid fi al-Lughah wa al-Aa'lam. Beirut: Daar al-Masyriq,

[17] Olidort J (2016) Inside the Caliphate's Classroom. Washington: The Washington Institute for Near East Policy.

[18] Johnston P, Jacob S, Howard J, Benjamin B, Danielle J., Patrick R. and Jonathan W (2016) Foundations of the Islamic State: Management, Money, and Terror in Iraq, 2005-2010. Santa Monica, CA: RAND Corporation.

[19] Peters R (1979) Islam and Colonialism: The Doctrine of Jihad in Modern History. The Hague: Mouton Publishers.

[20] al-Qaradhawi Y (2009) Fiqhul Jihad. Al-Qahira: Dar al-Kutub al-Misriyya.

[21] Rabil R (2018) Contextualizing jihad and takfir in the sunni conceptual framework. (Aug 31, 2018). Available at: https://www.washingtoninstitute.org/policy-analysis/contextualizing-jihad-and-takfir-sunniconceptual-framework\#main-content (accessed 20 October 2020).

[22] Sulaiman U (2017) A'an al-Dahbih Wa Qati' al-Ru'us fil Islam (On slaughtering and beheading in Islam). Available at: https://raseef22.net/article/890-\%D8\%B9\%D9\%86- (accessed 10 November 2020)

[23] al-Tabari M (2000) Jami' al-Bayan fi Ta'wil al-Qur'an. Beirut: Muassasah al-Risalah.

[24] al-Tirmidhi A (2018) Sunan al-Tirmidhi. Cairo: Dar al-Ta'aseel

[25] Wodak R, de Cillia R, Reisigl M and Liebhart K (2009) The Discursive Construction of National Identity. Edinburgh: Edinburgh University Press. 


\section{Appendix}

\section{Data Sources}

jihadology.net, http://www.clarionproject.org/news/islamic-state-isis-isil-propaganda-magazinedabiq (accessed 20 October 2020).

https://www.pinterest.com/wisdpisocstu/isisisil-resources-for-teachers/ (accessed 16 November 2020).

https://www.businessinsider.com/isis-textbooks-2016-8 (accessed 23 October 2020). 